\title{
Analisis Kecenderungan Manhaj Akidah Shaykh Shams al-Din al-Sumatera'i
}

\author{
An Analysis on Theological Method of Shaykh Shams al-Din al-Sumatera'i
}

\author{
MOHD HAIDHAR KAMARZAMAN* \& ABDULL RAHMAN MAHMOOD ${ }^{1}$
}

\begin{abstract}
Shaykh Shams al-Din al-Sumatera'i is a very great and respected scholar during 16 th and 17th century of Acheh. His knowledge in various fields recognized by local and international scholars. He had been a Qadi Malik al-'Adil, a religious leader, who became a referred by communities and country during the reign of the three Sultans of Aceh. He has authored nearly 40 pieces of books related to the theology and sufism. This study focuses on the methods used by Shaykh Shams al-Din alSumatera'i in his theological writings. This study found that Shaykh Shams al-Din al-Sumatera'i had used six methods in the such writings.
\end{abstract}

Keywords: al-Sumatrani, Shams al-Din Pasai, theology, theological method

Abad ke-17 Masihi merupakan abad yang terpenting dalam perkembangan akidah di Aceh. Ini kerana setelah kejatuhan kerajaan Melaka pada 1511 Masihi, Aceh menjadi tempat tumpuan perkembangan dan penyebaran dakwah Islam di seluruh Nusantara dan antarabangsa sama ada melalui perdagangan mahupun melalui ulama-ulama di Aceh. Shaykh Shams al-Din alSumatera'i merupakan salah seorang tokoh ulama yang hidup sekitar abad tersebut dan merupakan mufti atau Qadi Malik al-'Adil di sepanjang tiga pemerintahan Sultan di Aceh iaitu bermula dengan Sultan Ala' al-Din Riayat Shah (1589-1604), Sultan Muda 'Ali Riayat Shah (1604-1607) dan juga Sultan Iskandar Muda Mahkota Alam (1607-1636). Malahan beliau juga menjadi rujukan kepada masyarakat terhadap apa juga permasalahan (T. Iskandar 1966: 149150).

Nama penuh beliau adalah Shaykh Shams al-Din Ibn 'Abd Allah al-Sumatera'i. Nama Shaykh Shams al-Din seringkali disandarkan dengan gelaran al-Sumatera'i sebagai nisbah beliau terhadap tanah yang pernah diduduki atau tanah kelahirannya iaitu Sumatera. Boleh juga disebut sebagai Shaykh Shams al-Din Pasai kerana Sumatera merupakan tanah yang pernah bertapak kerajaan Samudera Pasai. Para sarjana bersepakat tidak dapat menentukan tarikh kelahirannya. Menurut Van Nieuwenhuijze (1945: 15), tiada dokumen atau apa-apa bukti yang dapat menunjukkan tarikh kelahiran Shaykh Shams al-Din al-Sumatera'i. Malahan sukar untuk dianggarkan tahun kelahirannya. Ini kerana dapatan bertulis yang ditemui hanya menyebut bahawa ketika zaman pemerintahan Sultan Ala' al-Din Riayat Shah (1589-1604) beliau sudah pun menjadi Shaykh al-Islam dalam pemerintahan Sultan Aceh.

Berdasarkan kepada kitab Bustan al-Salatin (al-Raniri 1907: 126), Shaykh Shams al-Din al-Sumatera'i wafat sekitar 12 Rejab 1039 Hijrah. Pada waktu itu Sultan Iskandar Muda sedang berusaha menakluki Melaka menitahkan tenteranya untuk menyerang Melaka. Shaykh Nur al-

\footnotetext{
1 Mohd Haidhar Kamarzaman*(Corresponding author), M.A., lecturer at the Dept. of Theology and Philosophy, Faculty of Islamic Studies, Universiti Kebangsaan Malaysia, 43600 BANGI, Selangor, Malaysia, email: haidhar@ukm.edu.my; Abdull Rahman Mahmood, Ph.D., senior lecturer at the Dept. of Theology and Philosophy, Faculty of Islamic Studies, Universiti Kebangsaan Malaysia, 43600 BANGI, Selangor, Malaysia, email: abrm@ukm.edu.my.
} 
Din al-Raniri (1907: 126-127) menggambarkan bahawa telah wafat seorang ulama yang alim dalam segala ilmu dan termasyhurnya ilmu beliau pada ilmu tasawuf dan beberapa kitab yang lain.

Tidak ramai guru Shaykh Shams al-Din al-Sumatera'i yang diketahui kerana terbatasnya penemuan mengenainya. Antara guru beliau yang diketahui adalah Hamzah Fansuri dan Sunan Bonang. Menurut A. Hasjmy (1976: 10) dan Hawasy Abdullah (1980: 41-42) Shaykh Shams alDin al-Sumatera'i adalah murid kepada Shaykh Hamzah Fansuri berdasarkan kepada dua karya Shaykh Shams al-Din al-Sumatera'i yang jelas mensyarahkan kitab karya Shaykh Hamzah Fansuri iaitu Ruba'i Hamzah Fansuri dan Syair Ikan Tongkol dengan judul Syarah Ruba'i Hamzah Fansuri dan Syarah Syair Ikan Tongkol. Manakala Winstedt (1977: 143) merekodkan bahawa, Shaykh Shams al-Din al-Sumatera'i juga pernah berguru dengan Pangeran Bonang di Pulau Jawa.

Antara karya Shaykh Shams al-Din al-Sumatera'i yang telah ditemui oleh penulis yang merangkumi berbagai bidang adalah, Bayan Allah, Kashf al-Sirr al-Rububiyyah Fi Kamal al'Ubudiyyah, A'yan Thabitah Wa A'yan Kharijiyyah, Risalah Mukhtasarah Fi Ahwal al-Mutaqaribin Ila Allah, Ma'rifat Allah, Fath al-Sirr, Bab al-Muqaranah, Risalah Jawami' al-'Amal, Anwar alDaqa'iq, Da'irat al-Wujud, Kashf Asrar al-Wujud, Risalat Mithal al-Wujud, Kelebihan Dan Kemuliaan Insan Daripada 'Alam Yang Lain, Risalat Masa'il Kalam al-Haqiqah, Haqiqat al-Sufi, Haqq al-Yaqin Fi'Aqidat al-Muhaqqiqin, Mira'at al-Mukmin, Kitab 'Aqidat al-Islam Fi Ma'rifat Tafsil al-Iman, Hifz al-Iman, Risalat Haqiqat al-Iman wa al-Islam, Jawhar al-Haqa'iq, Risalah Tubayyin Mulahazat al-Muwahhidin wa al-Mulhidin, Sharh Ruba'i Hamzah Fansuri, Tariq alSalikin Wa Sabil al-Sa'irin, dan yang terakhir adalah Sharh Syair Ikan Tongkol yang merupakan antara kitab terbesar Shaykh Shams al-Din al-Sumatera'i dalam mensyarahkan syair-syair Shaykh Hamzah Fansuri.

\section{Shaykh Shams al-Din al-Sumatera'i dalam Persoalan Manhaj Akidah}

Dalam mengkaji dan meneliti karya Shaykh Shams al-Din al-Sumatera'i, tidak terdapat penyataan secara langsung yang merujuk kepada manhaj yang diguna pakai dalam penulisan beliau mengenai persoalan akidah. Namun terdapat penyataan secara tidak langsung wujud dalam karya-karyanya yang menyebut beberapa perkara yang berkaitan dengan metodologi pemikiran akidah beliau.

Sebelum dijelaskan manhaj beliau, terlebih dahulu perlu diperjelaskan bahawa Shaykh Shams al-Din al-Sumatera'imerupakan seorang ulama Ahli Sunah Waljamaah dalam akidah. Terdapat beberapa karyanya yang menjelaskan perkara tersebut dan juga petikan-petikan pendapat Ahli Sunah Waljamaah berhubung dengan persoalan akidahnya. Shaykh Shams al-Din al-Sumatera'i menjelaskan dalam kitab Mira'at al-Mu'min (al-Sumatera'i t.th. a: 3)

Wa Ba'du, adapun kemudian dari itu, maka pada hijrah seribu sembilan tahun daripada hijrah Nabi Allah pada hari khamis pada sembilan belas hari bulan Dhulqa'idah bahawa Shaykh Shams al-Din ibn 'Abd Allah menta'lifkan risalat ini dengan bahasa Jawi pada menyatakan perkataan Usul al-Din daripada iktikad Ahl al-Sunah Waljamaah.

Oleh itu secara tidak langsung manhaj Ahli Sunah Waljamaah merupakan manhaj beliau dalam persoalan akidah. Setelah dianalisis kitab-kitab beliau dapatlah dirumuskan bahawa manhaj yang diikuti oleh Shaykh Shams al-Din al-Sumatera'i dalam pemikiran akidah beliau sebagaimana berikut: 


\section{Objektif Sebagai Asas dalam Setiap Penulisan}

Shaykh Shams al-Din al-Sumatera'i merupakan seorang ulama yang sangat produktif dalam penulisan akidahnya. Beliau mempunyai idea-idea yang bernas serta hujah-hujah yang jitu dalam memperkenalkan dan memberi kefahaman kepada masyarakat mengenai akidah Islam. Salah satu daripada metodologi yang digunakan dalam penulisan beliau adalah penetapan objektif dalam setiap karyanya. Kitab-kitab atau risalah-risalah yang dikarang oleh Shaykh Shams al-Din al-Sumatera'i mempunyai objektif tertentu dalam menyampaikan penjelasan kepada masyarakat. Bukan hanya kitab akidah beliau sahaja, malahan kitab-kitab tasawuf beliau juga mencerminkan metodologi ini dalam setiap penulisannya.

Setiap karya yang mempunyai objektif adalah merupakan karya yang terancang dan tersusun kerana penulis yang menetapkan objektif dalam penulisannya adalah penulis yang mempunyai sasaran hasil yang berpaksikan kepada objektif yang telah ditetapkan bagi setiap penulisannya. Dalam karya-karya yang dihasilkan oleh al-Sumatera'i dapat dilihat bahawa penulisan yang dilakukan oleh beliau merupakan penulisan yang terancang dan tersusun serta tidak bersifat subjektif dalam usaha untuk menjelaskan mengenai isi kandungan perkara yang hendak dibicarakan dalam kitab tersebut. Beliau mempunyai sasaran yang jelas dalam membicarakan topik yang diutarakan dalam setiap penulisannya. Sebagai contoh, dalam kitab Mir'at al-Mukmin beliau menjelaskan bahawa (al-Sumatera'i t.th. a: 3):

Wa Ba'du, adapun kemudian dari itu, maka pada hijrah seribu sembilan tahun daripada hijrah Nabi Allah pada hari khamis pada sembilan belas hari bulan Dhulqa'idah bahawa Shaykh Shams al-Din ibn 'Abd Allah menta'lifkan risalat ini dengan bahasa Jawi pada menyatakan perkataan Usul al-Din.

Begitu juga dalam kitab Risalah Haqiqat al-Iman Shaykh Shams al-Din al-Sumatera'i menyatakan tujuan beliau menulis risalah tersebut:

$W a b a ' d u$. Adapun kemudian dari itu maka ini risalah pada menyatakan sebenarbenar iman, ketahui hai talib al-din sesungguhnya yang bernama iman itu tasdiq artinya disungguhkan seseorang dan diiktikadkan dalam hatinya akan ada Zat allah Ta'ala yang laysa kamithlihi shay', artinya yang tiada sebagainya sesuatu.

Dalam hampir kesemua kitab-kitabnya yang lain, beliau menyatakan objektif perbincangan dan penulisan beliau yang menunjukkan bahawa beliau merupakan seorang ulama yang meletakkan objektif dan sasaran pembaca. Melihat kepada kitab-kitab yang dihasilkan, boleh dikatakan bahawa beliau telah merangka penulisan dan sasaran pembaca sebelum beliau menulis satu-satu kitab.

\section{Peranan Bahasa dalam Penjelasan Akidah}

Shaykh Shams al-Din al-Sumatera'i juga merupakan seorang ulama yang terkenal bijaksana dalam bidang bahasa. Hal ini dibuktikan daripada tulisan Sir James Lancaster (1940: 96) yang pernah merekodkan mengenai kefasihan dan kefahaman yang baik dalam bahasa Arab oleh Shaykh Shams al-Din al-Sumatera'i ketika melakukan perundingan perjanjian damai antara Inggeris dan Aceh:

Salah seorang dari dua tokoh terkemuka ini adalah chiefe bishope wilayah itu. Orang yang sangat dihormati oleh Raja dan seluruh rakyat, dan memang dia patut dihormati kerana dia adalah orang yang sangat bijaksana dan tenang. Yang lain adalah seorang bangsawan yang sangat kuno, orang yang berada tetapi tidak 
sesuai untuk mengikuti pertemuan-pertemuan sebagaimana chief bishop. Dan seluruh pertemuan berlangsung dalam bahasa Arab, yang sangat difaham dengan baik oleh chiefe bishop mahupun oleh tokoh terkemuka yang satunya lagi.

Begitu juga Shaykh Shaykh Nur al-Din al-Raniri pernah menyatakan bahawa Shaykh Shams al-Din al-Sumatera'i adalah seorang yang fasih berbicara dalam bahasa Arab dan layak untuk mengikuti apa-apa bentuk perundingan dengan utusan antarabangsa. Al-Raniri (1907: 129-130) menyatakan:

Fasih berbicara dalam bahasa Arab dan layak untuk mengikuti perundingan antara Aceh dan utusan-utusan dari luar negeri.

Selain itu juga Shaykh Shams al-Din al-Sumatera'i merupakan seorang ulama yang banyak menulis kitab-kitab yang berbahasa Arab dan menterjemahkan kitab-kitab berbahasa Arab. Sebagai contohnya kitab yang ditulis dalam bahasa Arab adalah Jawhar al-Haqa'iq, Risalah Tubayyin, Kitab al-Hirqah dan lain-lain. Manakala kitab yang diterjemahkan dari bahasa Arab pula antaranya Mira'at al-Mu'min. Hal ini juga telah membuktikan bahawa beliau adalah merupakan seorang tokoh ulama yang alim dalam bidang bahasa. Kerana itu dalam kerangka penulisannya tidak akan terlepas istilah-istilah yang akan didefinisikan oleh beliau sama ada dari sudut bahasa mahupun Istilah. Beliau akan berusaha untuk memahamkan pembaca terlebih dahulu sebelum beralih kepada makna literal dan kandungan yang akan dijelaskan kemudiannya.

Dalam setiap permulaan topik perbincangan, beliau akan memberikan takrif sesuatu istilah atau perkataan yang akan digunakan secara konsisten sehingga akhir penulisannya dalam satu-satu karya sebagai contohnya dalam Mira'at al-Mu'min, beliau akan menjelaskan definisi terlebih dahulu dalam topik perbincangan. Apabila membincangkan mengenai isu sifat dan af'al Allah beliau akan memberikan takrif sifat zat dan sifat af'al terlebih dahulu sebelum mebicarakan kandungan topik tersebut (al-Sumatera'i t.th. a: 6):

هahawa takrif sifat Afal itu pada mereka itu والمجارة تعلق الإرادة والقدرة بالمرادة ertinya iaitu rajan daripada ta'alluq sifat Iradah dan Qudrah dengan segala Murad-Nya dan segala Maqdur-Nya. Maka kembali segala sifat Af'al itu kepada kandungan sifat Takwin maka bi aqwalih ta'alluqIradah dan Qudrah yang menyampaikan khalq kepada makhluq dan rizq kepada marzuq dan barang yang lain daripada itu.

هahawa takrif sifat Dhat itu هي القائمة بذاته التي لزم من وجوده وجودها وجود الإنفكالك لما عندا ابدا ertinya iaitu yang berdiri ia dengan zat-Nya yang lazim daripada ada zat-Nya ada segala sifat-Nya dengan ada yang tiada tinggal segala sifatnya itu daripada zatNya iaitu seperti sifat yang tujuh yang tersebut itu atau barang yang lain dari itu.

Selain bentuk pendefinisian secara langsung, beliau juga sering memberikan contoh terhadap pendefinisian tersebut seperti (al-Sumatera'i t.th. a: 5):

Bahawa pengenal kita akan af'al Allah bahawa Allah Ta'ala bersifat dengan sifat af'al Allah seperti takhliq dan tarziq dan ihya' dan amat dan ihda' dan idlal.

Allah Subhanahu Wa Ta'ala itu bersifat hayah dan ilm dan iradah dan qudrah dan sama' dan basar dan kalam ertinya peri hidup dan tahu dan berkehendak dan 
kuasa dan mendengar dan melihat dan berkata-kata dan barang yang lain dari itu daripada segala sifat Zat-Nya itu.

Begitu juga yang terdapat dalam topik-topik perbincangan yang lain seperti persoalan mengenai tauhid, iman, nabi, malaikat dan persoalan-persoalan yang lain terutamanya apabila membicarakan perbahasan ilmu akidah. Ini kerana bagi beliau perbahasan kepada ilmu akidah ini perlukan kepada kefahaman yang jitu dan sasaran pembacanya adalah orang awam yang menjadi fardhu ain ke atas mereka untuk mengetahuinya.

\section{Penghujahan Naqli Sebagai Asas Dalil Qat'i}

Metode penghujahan naqli adalah merupakan salah satu metode yang diguna pakai oleh kesemua ulama Ahli Sunah Waljamaah kerana ianya merupakan penghujahan paling utama dalam menjelaskan akidah Islam. Shaykh Shams al-Din al-Sumatera'i dilihat meletakkan keutamaan kepada naqli berbanding dari sesuatu yang lain. Banyak bukti yang menunjukkan bahawa beliau meletakkan asas manhaj ini sebagai manhaj yang utama dalam mengisbatkan permasalahan akidah. Hal ini disebut oleh Shaykh Shams al-Din al-Sumatera'i dalam karyanya Mir'at al-Mukmin bahawa dalil naqli adalah terdiri daripada nas al-Quran, Sunah, Ijmak iaitu Ijmak para Sahabat, (al-Sumatera'i t.th. a: 45):

Soal: Jika ditanyai orang kita yang mana bernama dalil itu?

Jawab: Bahawa yang bernama dalil itu Kitab Allah yakni Quran dan Sunnah Nabi yakni Hadith Nabi Allah dan Ijmak segala Sahabat yakni ittifaq mereka itu.

Dalam kitab-kitab Shaykh Shams al-Din al-Sumatera'i terutamanya mengenai perbahasan akidah, seringkali penghujahan menggunakan dalil naqli ini ditonjolkan. Ianya bagi menjelaskan kepada masyarakat bahawa betapa pentingnya hujah naqli ini untuk menjadi satu bukti yang kuat dan kukuh untuk dijadikan pegangan akidah bagi setiap muslim. Dalil naqli ini menjadi dalil utama dalam setiap topik perbahasan yang dibincangkan. Sebagai contohnya dalam dalam menjelaskan mengenai Zat Allah (s.w.t.) yang tiada seumpamanya, Shaykh Shams al-Din al-Sumatera'i (t.th. (a): 4) menyatakan:

Bahawa pengenal kita akan zat Allah ituء لبس كمثلك شي (al-Quran 42: 11) ertinya tiada sebagai-Nya suatu dan bahawa zat Allah itu Esa tiada sekutu bagi-Nya.

Demikian juga dalam menjelaskan persoalan syahadah, Shaykh Shams al-Din al-Sumatera'i menggunakan dalil daripada Hadith Qudsi yang menjelaskan bahawa wajib bagi seseorang itu bersaksi bahawa tiada Tuhan melainkan Allah dan disertakan dengan kesaksian terhadap kebenaran Nabi Muhammad (s.a.w.). Shaykh Shams al-Din al-Sumatera'i (t.th. a: 19) menyatakan:

منع كمال الإمان بشهادة التوحيد ما لم يقترن Kerana firman Allah Ta'ala dalam Hadith Qudsi ertinya tertegah sempurna iman seseorang dengan syahadah tauhid yakni أشهـ أن لا إله إلا الشه itu.

\section{Pengujahan Akal Memandu Kaedah dan Asas Penggunaan Dalil Naqli}

Akal merupakan anugerah Allah (s.w.t.) kepada manusia. Ahli Sunah Waljamaah meletakkan akal pada kedudukan yang tinggi bagi tujuan memahami ilmu akidah. Dalam penghuraian Shaykh Shams al-Din al-Sumatera'i terhadap isu-isu akidah yang dibangkitkan dalam kitabnya, 
hujah akal sentiasa seiring dengan perbahasan yang beliau kemukakan terutamanya dalam perkara-perkara akidah. Walaubagaimanapun dapat dilihat dalam pemikiran akidah Shaykh Shams al-Din al-Sumatera'i bahawa hujah akal ini digunakan sebagai penyokong yang kuat kepada dalil naqli bagi menghuraikan kefahaman dengan lebih mendalam terhadap satu-satu isu yang dikemukakan. Dalam kitab Mira'at al-Mukmin, Shaykh Shams al-Din al-Sumatera'i menyebut bahawa pendalilan itu juga adalah melalui akal (al-Sumatera'i t.th. a: 46):

Maka imannya kita akan Zat Allah Ta'ala dan ada segala Sifat-Nya dan ada segala fi'l-Nya dengan dalil akal dan iman kita akan benar Nabi Muhammad Rasulullah Sallallahu 'Alayh Wa Sallam itu pun dengan dalil naqli dan dengan akli jua.

Di antara contoh penghujahan akal yang digunakan oleh Shaykh Shams al-Din alSumatera'i dalam persoalan akidah adalah bukti kewujudan Allah (s.w.t.). Dalil mengenai kewujudan Allah (s.w.t.) yang juga digunakan oleh Shaykh Shams al-Din al-Sumatera'i adalah sama seperti beberapa ulama kalam sebelumnya iaitu dalil huduth al-'alam (al-Sumatera'i t.th. (a): 47):

Bermula dalil 'aqli itu iaitu baharu alam kerana jika tiada ada bagi alam itu yang menjadikan dia nescaya jadi ia sendirinya dan akan dalil kita dengan dalil 'aqli akan baharu alam itu, mengekali dia segala 'arad yang baharu daripada harakah dan sukun atau barang yang lain daripada keduanya dan yang mengekali baharu itu baharu jua dan dalil kita dengan dalil 'aqli akan baharu segala 'arad itu dipandang ubahnya daripada tiada kepada ada dan daripada ada kepada tiada.

Pendapat-pendapat Shaykh Shams al-Din al-Sumatera'i ini menjelaskan bahawa setiap manusia perlu beriktikad dengan sesuatu yang mencapai tahap keyakinan, bukan hanya semata-semata menerima tanpa pembuktian. Kerana apabila seseorang itu beriman dengan iman yang menerima secara membuta tuli, maka iktikad tersebut merupakan iktikad yang taqlid sedangkan iktikad yang sebenarnya perlu wujud dalam diri seorang manusia adalah iktikad jazmi (al-Sumatera'i t.th. a: 45).

Walaupun perbincangan mengenai taklid tidak diperbahaskan secara terperinci, tetapi jelas bahawa Shaykh Shams al-Din al-Sumatera'i melarang untuk beriktikad dengan taklid secara membuta tuli, bahkan beliau mengambil pendekatan untuk memperjelaskan hujah-hujah akal bagi memperkukuhkan keyakinan akidah manusia dalam setiap penulisannya. Beliau menghuraikan dalil akal untuk menjelaskan jalan keluar kepada orang beriman daripada iktikad taklid kepada iktikad jazam.

Antara contoh dalil akal yang digunakan Shaykh Shams al-Din al-Sumatera'i adalah ketika beliau mengisbatkan bagi Allah (s.w.t.) sifat mukhalafah li hawadith (al-Sumatera'i t.th(a): 48): “...jika sebagai Ia dengan sesuatu daripada segala muhdath, nescaya Ia adalah muhdath sebagai dengan Dia, maka ianya muhal" (Jika Allah seumpama dengan sesuatu daripada segala muhdath, nescaya Allah itu adalah muhdath sebagaimana muhdath itu seumpama-Nya, maka itu adalah mustahil). Daripada penghujahan ini dapatlah kita rumuskan bentuk qiyas yang terkandung dalam kenyataannya seperti berikut:

Premis Pertama: Jika Allah seumpama dengan sesuatu daripada segala muhdath, nescaya Allah itu adalah muhdath sebagaimana muhdath itu seumpama-Nya.

Premis Kedua : Keadaan Allah (s.w.t.) itu muhdath adalah mustahil

Kesimpulan : Keadaan Allah (s.w.t.) menyerupai sesuatu yang baharu adalah mustahil. 
Kesimpulannya dapat dirumuskan bahawa banyak isu akidah yang dibincangkan oleh Shaykh Shams al-Din al-Sumatera'i telah dijelaskan oleh beliau dengan memperkukuhkannya dengan hujah-hujah akal antaranya adalah isu ketuhanan dan kenabian sebagai penyokong kepada hujah-hujah naqli yang dibawa. Sungguhpun begitu dapat dilihat bahawa keutamaan dalil naqli sebagai dalil asas bagi Shaykh Shams al-Din al-Sumatera'i masih lagi dikekalkan.

\section{Isu Khilafiyyah dalam Persoalan Akidah}

Dalam metode Shaykh Shams al-Din al-Sumatera'i terhadap persoalan khilafiyyah, secara umumnya Shaykh Shams al-Din al-Sumatera'i boleh dikatakan banyak menyentuh persoalanpersoalan khilafiyyah terhadap beberapa isu akidah. Beliau menyentuh isu-isu khilafiyyah ini sama ada khilaf yang timbul dari kalangan kelompok sesama Ahli Sunah Waljamaah mahupun khilaf yang timbul dia antara golongan Ahli Sunah Waljamaah dan golongan yang bertentangan dengannya. Namun dalam banyak keadaan, isu-isu khilafiyyah ini sering disentuh hanya sepintas lalu sahaja tanpa memperincikan perbahasannya. Sebagai contohnya dalam persoalan sifat ja'iz bagi Allah Ta'ala, beliau hanya menyentuh perbezaan pendapat di antara Imam Shafi'i dan Imam Hanafi tetapi tidak memperincikan perbahasannya lebih mendalam. Shaykh Shams al-Din al-Sumatera'i menyatakan (t.th. a: 11)

Bahawa sifat yang ja'iz pada Allah Ta'ala pada mazhab Imam Shafi'i Radiyallahu 'Anh segala sifat fi'l seperti ihda' dan idlal dan ihya' dan amat dan tarziq dan takhliq dan yang perhimpunan sekalian itu dari sifat takwin maka dengan takwin Allah itulah jika berkehendak Ia menjadikannya suatu, jika tiada Ia berkehendak maka tiada, kerana itulah kata ulama ilmu usul al-din bahawa ja'iz pada Allah Ta'ala itu menjadikan alam itu tiada. Adapun pada mazhab Imam Hanafi Radiyallahu 'Anh bahawa sifat fi'l itu qadim maka ja'iz pada Allah Ta'ala ta'alluqnya yang mumkinal-wujud yakni jika hendak Ia menjadikan dia dijadikanNya, jika tiada Ia berkehendak maka tiada.

Berkemungkinan metode Shaykh Shams al-Din al-Sumatera'i terhadap persoalanpersoalan ini tidak terlalu mendalam kerana kitab ini ditujukan pada orang awam. Walaubagaimanapun terdapat juga beberapa isu khilafiyyah yang dipandang oleh Shaykh Shams al-Din al-Sumatera'i sebagai isu yang penting sehingga memerlukan penjelasan yang lebih spesifik. Kerana itu penjelasan mengenai metode beliau ini dapat dirumuskan kepada dua bahagian, pertamanya metode Shaykh Shams al-Din al-Sumatera'i terhadap perselisihan daripada golongan yang bertentangan dengan Ahli Sunah Waljamaah, kedua metode Shaykh Shams al-Din al-Sumatera'i terhadap perselisihan di kalangan golongan Ahli Sunah Waljamaah.

\section{Metode terhadap Golongan yang Bertentangan dengan Ahli Sunah Waljamaah}

Berhubung dengan isu khilafiyyah terhadap golongan yang bertentangan dengan Ahli Sunah Waljamaah, Shaykh Shams al-Din al-Sumatera'i akan menjelaskan pendapat-pendapat mereka terdahulu secara spesifik. Setelah itu beliau mengemukakan pendapat yang dipegang oleh ulama-ulama Ahli Sunah Waljamaah. Dengan pendapat-pendapat Ahli Sunah Waljamaah ini secara tidak langsung menolak pandangan golongan yang menyeleweng tersebut. Lebih jauh lagi, dalam sesetengah isu, metode Shaykh Shams al-Din al-Sumatera'i adalah keras, beliau membawa prinsip yang tegas sehingga menghukumkan kafir kepada mereka yang bertentangan pendapat dengan Ahli Sunah Waljamaah. Sebagai contohnya dalam persoalan Qadar, Shaykh Shams al-Din al-Sumatera'i mengemukakan khilaf di antara golongan Qadariyyah dan Jabariyyah secara spesifik. Seterusnya beliau membawa pendapat yang dipegang oleh Ahli Sunnah Waljamaah dan dalam masa yang sama menolak pendapat-pendapat yang 
menyeleweng. Akhir sekali dengan tegas Shaykh Shams al-Din al-Sumatera'i mengkafirkan golongan Qadariyyah dan Jabariyyah. Shaykh Shams al-Din al-Sumatera'i (t.th. a: 43, 44, 86) menyatakan:

Bahawa iktikad kaum Qadariyyah dan kata mereka itu untung baik daripada Allah Ta'ala dan untung jahat daripada diri dan iktikad kaum Jabariyyah dan kata mereka itu untung baik dan jahat daripada Allah Ta'ala tetapi tiada bagi kita hamba Allah fi'l ikhtiyar dan iktikad Ahli Sunnah Waljamaah dan kata mereka itu untung baik dan jahat daripada Allah Ta'ala tetapi ada bagi hamba fi'l ikhtiyar dan dengan fi'l ikhtiyar itulah dikurniai pahala akan kita dan siksa akan kita tetapi siksanya itu dengan adil-Nya dan pahala itu dengan kurnia-Nya.

Soal: Jika ditanyai orang kita bahawa kaum Qadariyyah dan kaum Jabariyyah itu kafirkah mereka itu atau tiada?

Jawab: Bahawa kaum yang kedua itu kafir.

Selain daripada itu di antara metode Shaykh Shams al-Din al-Sumatera'i terhadap persoalan khilafiyyah adalah dengan menjelaskan pada setiap isu akidah akan iktikad lawannya yang boleh membawa kepada kekufuran. Sebagai contohnya dalam masalah sifat Allah Shaykh Shams al-Din al-Sumatera'i (t.th. b: 6):

Maka barangsiapa menafikan zat Allah Ta'ala atau menafikan sesuatu daripada segala sifat zat yang tersebut itu atau menafikan sesuatu daripada segala fi'l-Nya yang tersebut itu nescaya jadi kafir ia, berlindung kiranya kita kepada Allah Ta'ala daripada kufur itu.

Shaykh Shams al-Din al-Sumatera'i berpaksikan manhaj ini kepada manhaj Ahli Sunah Waljamaah yang menjadi teras dalam pemikiran akidahnya. Dalam perkara usul, Shaykh Shams al-Din al-Sumatera'i sangat tegas terhadap prinsip-prinsip yang telah disepakati oleh para ulama Ahli Sunah Waljamaah. Kerana itu beliau telah mengkafirkan mereka yang mengingkari usul akidah.

\section{Metode terhadap Golongan Berselisihan dengan Ahli Sunah Waljamaah}

Terdapat dua metode Shaykh Shams al-Din al-Sumatera'i dalam persoalan khilafiyyah di kalangan Ahli Sunah Waljamaah. Pertamanya, apabila tiba pada persoalan khilafiyyah di kalangan Ahli Sunah Waljamah beliau tidak menyatakan bahawa isu tersebut adalah isu khilafiyyah, tetapi menyatukan kedua-dua pandangan tanpa menjelaskan mengenai khilaf di kalangan mereka. Sebagai contohnya dalam masalah sifat Allah, terdapat perbezaan di kalangan Ahli Sunah Waljamaah dalam mengisbatkan sifat takwin pada sifat. Golongan al-Maturidiyyah berpendapat bahawa takwin sebagai salah satu sifat Dhat Allah (s.w.t.), manakala al-Asha'irah pula mengeluarkannya dari sifat Dhat Allah (s.w.t.) dan memasukkannya dalam perbahasan sifat fi'l di bawah ta'alluq sifat qudrah. Walaubagaimanapun takwin itu dijelaskan sebagai $a f^{\prime} a l$ Allah sebagaimana yang dijelaskan oleh Shaykh Shams al-Din al-Sumatera'i (t.th. b: 5-6):

Bahawa sesungguhnya Allah Ta'ala itu zatnya laysa kamithlihi shay' artinya adaNya yang tiada sebagai-Nya sesuatu dan yang bersifat dengan sifat Zat iaitu wujud dan qadim dan baqa' dan mukhalafatuh lil hawadith dan qiyamuhu bi nafsih dan wahdaniyyah dan hayah dan ilmu dan iradah dan qudrah dan sama' dan basar dan kalam dan hayy dan alim dan murid dan qadir dan sami' dan basir dan mutakallim, artinya ada dan sedia dan kekal dan bersalahan dengan segala 
yang muhdath dan berdiri dengan sendiri-Nya dan Esa dan hidup dan tahu dan berkehendak dan kuasa dan mendengar dan melihat dan berkata dan yang hidup dan yang tahu dan yang berkehendak dan yang kuasa dan yang mendengar dan yang melihat dan yang berkata dan yang bersifat dengan sifat fi'l iaitu ihda dan idlal dan ihya' dan amat dan tarziq dan takhliq artinya menunjuk jalan betul dan yang tersebut dan yang menghidupkan dan mematikan dan yang memberi untung dan yang menjadikan dan yang berhimpun sekalian sifat fi'l itu dalam sifat takwin artinya mengadakan.

Keduanya, apabila bertemu sesuatu isu yang khilaf kalangan Ahli Sunah Waljamaah, Shaykh Shams al-Din al-Sumatera'i akan menjelaskan secara terperinci kedua-dua pendapat. Kemudian beliau akan mengemukakan tarjihkepada pendapat yang lebih asah dan diterima pakai. Sebagai contohnya dalam persoalan bid'ah dan golongan mubtadi', Shaykh Shams al-Din al-Sumatera'i menjelaskan pendapat-pendapat ulama mengenai hukum mereka. Lalu beliau mentarjihkan pendapat tersebut. Shaykh Shams al-Din al-Sumatera'i (t.th. a: 67) menyatakan:

Soal: Jika ditanyai orang kita apa hukum mubtadi' itu?

Jawab: Bahawa hukum mubtadi' itu ikhtilaf segala ulama dalamnya, kata setengah mereka itu bahawa mubtadi' itu tiada kafir dan kata setengah mereka itu segala mubtadi'itu sekaliannya kafir dan kata setengah mereka itu jika zahir daripadanya kufur maka dihukumkan ia kafir dan jika tiada zahir daripadanya kufur maka tiada ia dihukumkan kafir tetapi ia 'asi maka kata ini kata yang asah pada segala ulama usul al-din.

Dalam hal ini, menurut Shaykh Shams al-Din al-Sumatera'i, terdapat dua pendapat ulama mengenai golongan $\mathrm{Ahl}$ al-Bid'ah. Sebilangan ulama berpendapat mereka ini dihukumkan sebagai kafir, dan sebilangan yang lain hanya meletakkan mereka dalam keadaan mukmin yang berdosa sahaja. Dalam khilaf ini, Shaykh Shams al-Din al-Sumatera'i menjelaskan pendapat yang paling sahih dari kesemua pandangan ulama untuk diguna pakai.

Begitu juga beliau mentarjihkan pendapat mengenai anak orang kafir yang mati sebelum baligh. Beliau menyatakan (al-Sumatera'i t.th. a: 87):

Soal: Jika ditanyai orang kita segala anak kafir yang masih belum baligh apa bila mati mereka itu masuk Syurgakah mereka itu atau masuk Neraka?

Jawab: Bahawa akan segala anak kuffar itu ikhtilaf segala ulama dalamnya, setengah mereka itu berkata masuk Neraka tetapi qawl yang asah daripada mereka itu bahawa mereka itu masuk Syurga tetapi pekerjaannya dalam Syurga berbuat khidmat mereka itu akan segala isi Syurga.

Dapat dilihat bahawa metode yang digunakan oleh Shaykh Shams al-Din al-Sumatera'i dalam isu khilafiyyah terhadap persoalan akidah ini adalah metode yang sederhana tetapi tegas. Penggunaan metode ini dalam persoalan khilafiyyah berkemungkinan adalah kerana sasaran beliau merupakan orang awam yang tidak mendalami masalah-masalah dalam ilmu kalam sehingga perlu kepada perbincangan yang mendalam terhadap khilaf-khilaf di kalangan para ulama kalam. Berbanding dengan metode yang digunakan terhadap perbahasan tasawuf dalam banyak kitab tasawuf beliau terutamanya dalam persoalan martabat tujuh, beliau dengan jelas menyatakan sasarannya bahawa orang yang benar-benar mendalami ilmu tasawuf baharulah boleh menjadi pembaca kepada kitab tersebut. 


\section{Penghayatan Akidah sebagai Manhaj Pendekatan Hikmah}

Bagi Shaykh Shams al-Din al-Sumatera'i, metode penghayatan akidah adalah sesuatu yang ditekankan. Kerana itu dalam penghayatan akidah, penggabungan antara teori dan amal mestilah seiring bagi setiap Muslim terutamanya dalam persoalan akidah. Ini kerana tanpa amalan, seseorang itu tidak boleh mencapai ke martabat yang lebih tinggi. Dalam metode Shaykh Shams al-Din al-Sumatera'i sendiri, beliau tidak mengutamakan perbahasan mengenai perselisihan para ulama tetapi perkara yang amat di utamakan adalah amal. Kerana itu khilaf di kalangan para ulama jarang dijumpai melainkan hanya pada tempat-tempat tertentu sahaja dalam kitabnya. Selain itu juga latar belakang Shaykh Shams al-Din al-Sumatera'i sebagai ulama tasawuf juga telah ditonjolkan dalam penulisannya di mana beliau mementingkan amal dalam penulisannya. Kerana itu dalam kitabnya banyak menyentuh mengenai amalan-amalan seorang salik sesuai dengan latar belakang ketokohannya dalam bidang akidah dan Tasawuf. Sebagai contohnya dalam kitab Risalah Jawami' al-'Amal, beliau membahaskan mengenai tingkatan salik dan amal yang perlu dilakukan mereka (al-Sumatera'i t.th.c: 1-2 ):

Maka sayugianya atas hamba Allah yang pilihan berbuat amal dengan amal yang empat perkara itu. Adapun amal orang syariat mengucap kalimah tawhid atau mengucap kalimah syahadah dan mendirikan sembahyang dan memberi zakat dan puasa bulan Ramadhan dan naik Haji ke Bayt al-Haram jika kuasa pergi kepadanya. Adapun amal orang tarikat taubat daripada dosa yang kecil dan yang besar tawakkal dan reda dan sabar dan taslim. Adapun amal orang hakikat mengesakan hak Subhanahu Wa Ta'ala dan mengesakan segala sifat zat-Nya dan segala sifat fi'l-Nya. Adapun amal orang makrifat senantiasa ia zikir dan muraqabah dan tawajjuh dan musyahadah akan yang dikenalnya yakni Allah Subhanahu Wa Ta’ala seperti yang diisyaratkan ustaznya kepadanya itu.

Kesimpulannya dapat dilihat kesan metode-metode yang digunakan oleh Shaykh Shams al-Din al-Sumatera'i ke dalam masyarakat Melayu pada zaman beliau dan zaman sesudahnya berhasil. Hal ini dibuktikan dengan sanjungan masyarakat dan kisah-kisah beliau sebagai tokoh ulama akidah dan sufi yang diriwayatkan dalam kitab-kitab lama dan penulisan pada hari ini. Pada zaman Shaykh Shams al-Din al-Sumatera'i merupakan waktu kegemilangan Islam di Aceh yang mana beliau juga merupakan salah seorang tokoh ulama yang bukan hanya dikenali di Aceh, malah seluruh dunia sehingga diberi penghormatan oleh ulama-ulama Mekah pada ketika itu dan juga dicatatkan gambaran mengenai dirinya oleh beberapa pelayar Eropah yang tiba di Aceh. 


\section{References}

Al-Quran.

A. Hasjmy. 1976. Ruba'i Hamzah Fansuri, Karya Sastera Sufi Abad XVII. Kuala Lumpur: Dewan Bahasa dan Pustaka.

Hawasy Abdullah. 1980. Perkembangan Ilmu Tasawuf dan Tokoh-Tokohnya di Nusantara. Surabaya: al-Ikhlas.

Lancester, J. 1940. The Voyages of Sir James Lancester to Brazil and the East Indies. Sunt. William Foster. London: The Hakluyt Society.

Al-Raniri, Shaykh Nur al-Din. 1907. Bustan al-Salatin. Dlm. Niemann. Bloemlezing uit Maleische Geschriften, II. 'S Gravehage: Martinus Nijhoff.

al-Sumatera'i, Shams al-Din. t.th. a. Mira'at al-Mu'min. Cod. Or. 1700. University of Leiden, Leiden.

al-Sumatera'i, Shams al-Din. t.th. b. Kitab 'Aqidat al-Islam fi Ma'rifat Tafsil al-Iman. MSS 3304(A). Koleksi Arkib, Perpustakaan Negara Malaysia.

al-Sumatera'i, Shams al-Din. t.th. c. Risalah Jawami' al-'Amal. MSS 1556(A). Koleksi Arkib, Perpustakaan Negara Malaysia.

T. Iskandar (Pnyt.). 1966. Bustan al-Salatin. Bab 2. Fasal 3. Kuala Lumpur: Dewan Bahasa dan Pustaka.

Van Nieuwenhuijze, C. A. O. 1945. Samsu 'L-Din Van Pasai: Bijdrage Tot De Kennis Der Sumatraansche Mystiek. Leiden: E. J. Brill. 